\title{
"Let Me With Sappho and Orinda Be oh Ever Sacred Nymph, Adorn'd by Thee", Aphra Behn: A Character in Search of an Author
}

\begin{abstract}
Tiziana Febronia Arena
University of Catania, Catania, Italy

In this paper, I will explore Aphra Behn's world: spy, kept mistress and writer. She created her complex personality between myth and reality, underlining limits and contradictions of her society in her life and works. In a world where woman had to be obedient she turned upside down a strict system, while remaining loyal to male libertinism. I will sketch out a brief outline of her life and works. She plays her role, assuming different positions, such as her masculine poetic gift and the labelled role of whore. This gave her access to the little but exciting world of women's literature. She constructed the image of the whore, becoming trader of herself. In doing this, she gained a place in society.
\end{abstract}

Keywords: Aphra Behn, Restoration, women's position

Among that number, do not me disdain, Me, the most humble of that glorious Train.

I by double right thy Bounties claim, Both from my Sex, and in Apollo's Name: Let me with Sappho and Orinda be

Oh ever Sacred Nymph, adorn'd by thee;

And give my Verses Immortality.

-Aphra Behn ${ }^{1}$

Aphra Behn: The Documentary Record (2004)

\section{Introduction}

Who is Aphra Behn?

As Mary Ann O’Donnell underlines, “[Behn is] a lethal combination of obscurity, secrecy and staginess, which makes her an uneasy fit for any narrative, speculative or factual. She is not so much a woman to be unmasked as an unending combination of masks". 2

Tiziana Febronia Arena, adjunct professor, Ph.D., Medical School, University of Catania.

1 Aphra Behn, in translating Cowley, broke the verses to introduce her own personal thoughts, showing her poetic Wit (quoted in Mary Ann O'Donnell. (2004). Aphra Behn: The documentary record. In Derek Hughes and Janet Todd (Eds.), The Cambridge companion to Aphra Behn. Cambridge, Cambridge University Press, p. 4.

2 Mary Ann O'Donnell. (2004). Aphra Behn: The documentary record. In Derek Hughes and Janet Todd (Eds), The Cambridge companion to Aphra Behn. Cambridge, Cambridge University Press, p. 1. 
The woman who corrupted the women of her century, as some critics have insisted on, and who gained an important role in Charles II's court and on the Restoration stages is, today, almost unknown by the general public. Her works have recently been the object of a recent surge of interest, especially in contemporary women's studies.

Exalted by feminists as the first professional woman writer, her life is shrouded in mystery. It seems that she constructed her own image, unveiling only the most interesting and mysterious fragments of herself to us, her readers. ${ }^{3}$ Without any doubt, she is a character of her own life.

\section{A Character in Search of an Author}

Nobody knows who she really was and what she really did in her life. It is believed that she probably was a courtesan, a spy, and a kept mistress. Books have been written about her but they read just like romances. ${ }^{4}$

Her name is doubtful as well; Janet Todd has written in this regard: "[With] its spelling variants of Affora and Afry, Afra, Eaffrey, Aphra was not common in Kent; it was the name of a saint martyred under Diocletian, traditionally supposed to have been a Cypriot prostitute converted to Christianity". ${ }^{5}$

As Colonel Thomas Colepepper wrote in Arcadia, she was born Johnson, at Canterbury, in $1640 .{ }^{6}$ She was the daughter, maybe, to a barber ${ }^{7}$ or maybe she was the foster-sister to the colonel. What is sure, according to many biographers of hers, is that she was not born a gentlewoman, ${ }^{8}$ but she was just as snobbish as any aristocratic woman. She was probably educated to the level of the aristocracy with her foster-brothers. ${ }^{9}$

Concerning this, Janet Todd writes:

Behn's lifelong faith in the aristocratic principle might suggest some noble connection, but it might also indicate inclination and desire, and it could be argued that the principle manifested itself for here more in style and culture than in political doctrine and relationships. ${ }^{10}$

In The History of Life and Memories of Mrs Behn, we can find her physical description. ${ }^{11}$ As Janet Todd has reported, she was undoubtedly quite attractive:

[She was] beautiful and witty, tall, well-built, even chubby perhaps, full-breasted, witty bright eyes, flowing brown hair, well-shaped mouth, and a small neck. [She loved competitions in rhyme and she played the flute]. She was sensual as much as sexual, interested both in men and women and appreciating beauty in both. Critical of others, she did not relish criticism of herself and she responded to rejection and withdrawal by falling ill. $^{12}$

As I have already said, her history has huge gaps that scholars have not been able to fill up. They have tried to answer to their questions through her works and characters, by making her into a character, as well.

In the 1660s, Aphra was probably hired by the English Government in the exotic colony of Surinam in South America. ${ }^{13}$ She was already an experienced spy, known as agent $160 .{ }^{14}$

\footnotetext{
3 Janet Todd. (1989). The sign of Angellica, women, writing and fiction, 1600-1800. Camden Town, London, Virago, p. 69.

${ }^{4}$ Ros Ballaster. (1998). Women's amatory fiction, from 1684 to 1740. Oxford, Clarendon Press, p. 69.

5 Janet Todd. (2000). The secret life of Aphra Behn. London, New York, Sidney, Pandora, p. 14.

${ }_{7}^{6}$ M. A. O'Donnell. Aphra Behn: The documentary record, op. cit., p. 1.

7 Angeline Goreau. (1980). Reconstructing Aphra, a social biography of Aphra Behn. New York, The Dial Press, p. 9.

8 Ibid., p. 11.

${ }^{9}$ Ibidem.

10 Aphra Behn. (2003). Oroonoko: The Rover and other works. Janet Todd (Ed.). London, Penguin Classics, p. 3.

11 J. Todd. The secret life of Aphra Behn, op. cit., p. 80

12 Ibidem.

13 Ibid., p. 35.

14 Ibid., p. 86.
} 
To that period does the relationship between the young Aphra, code name "Astrea", and the son of the regicide, William Scot, a.k.a. "Celadon", date. No hints at an amorous relationship between the two agents have been found, but a long-lasting friendship. "Scot and Behn formed an island of loyalty in a sea of corruption". 15 In this respect, Janet Todd points out,

In 1663 a Royal grant gave exploration of Surinam to Lord Willoughby. According to the "Memories" shortly afterwards Aphra Behn travelled to Surinam where it was claimed her father had been appointed "Lieutenant-General" of many islands and the continent of Surinam because of his relationship to Lord Willoughby. ${ }^{16}$

It was in Surinam that she imagined Oroonoko and planned The Young King. The latter is a fashionable tragicomedy of a royal brother and sister, Orsames and Cleomena, the first forced into seclusion the other obliged to act and to live as a man. Some centuries in advance, Aphra Behn explores gender issues and gender troubles which will find a solution at the end in a re-organization of natural roles (when they) throw off the disguise of nurture. ${ }^{17}$ According to Janet Todd, The Young King deals "with heroic lovers speaking blank verse, passages of courtly dialogue, and a concoction of Arcadia shepherds, symbolic pastures, magic cures and absolute disguise". ${ }^{18}$

Before returning to England she visited Virginia, where she set The Widow Ranter, the first English play to be set in the American colonies. ${ }^{19}$ In it, Behn explores America and the rebellions against the English Governors. What is interesting is the division she makes of a world formed only by men, those of the New World and those of England. She develops ideas of honour, identity by abandoning the standards of the old traditional respectability, inherited through noble birth, typical among Tories and Royalists as she was. Moreover, "she portrayed the robust Widow Ranter, who manages by adroit seduction to become an independent person of considerable means". 20

Back in England, she probably had a role in the Restauration of the Monarchy. Angeline Goreau has described an instable situation, and,

In the spring of 1659, the exiled King was at Breda, in Holland, attempting to organize a Royalist rebellion to further his return in England. One of these principal advisers was Lord Willoughby. [...] Among the Cavaliers whose aid he enlisted in this project was Colonel Thomas Culpepper, Aphra's "foster bother", who was to raise a cavalry troop in Canterbury. ${ }^{21}$

Because of her beauty, she was dragged and involved into the plot, becoming adept at imitation and dissimulation. $^{22}$

To understand better the character of Aphra Behn, it is fundamental to consider the contrasts of her Age. Religious and political tensions between Roundhead and the Exiled Cavaliers were the keystones of Aphra's contemporary society. The unflagging fear of a coup d'état, on the Roundheads' side, and the attempt to re-establish the Monarchy in England, on the other side, saw the young Aphra probably in the front line, with her foster-brother Colepepper, and with her friend Killigrew. ${ }^{23}$

15 Ibid., p. 98.

16 A. Behn. Oroonoko: The Rover and other works, op. cit., p. 4.

17 J. Todd. The secret life of Aphra Behn, op. cit., p. 64.

18 Ibidem.

19 A. Behn. Oroonoko, The Rover and other works, op. cit., p. 5.

20 J. Todd. The secret life of Aphra Behn, op. cit., p. 53.

21 A. Goreau. Reconstructing Aphra, op. cit., p. 20.

22 J. Todd. The secret life of Aphra Behn, op. cit., p. 31.

23 A. Goreau. Reconstructing Aphra, op. cit., p. 84. 
Supporter of the Tory Party, in 1681 she wrote The Roundheads in 1681. There, she connects Royalism with virtue. Moreover, she turns upside down the puritan ideas associating them with lust and secret longing. What results evident from her work is that "Royalism is especially associated with chastity, as the heroine Lady Desbro refuses to be unfaithful to her parliamentarian husband". ${ }^{24}$

All espionage offers were linked to her friend Killigrew, as The Secret Life of Aphra Behn reports,

Aphra was later employed for a dangerous mission, [because, as I have previously said] in such unfavourable circumstances, an attractive, youngish woman is unlikely to have been dispatched without any counterfeiting past, some proof that she would not spring a treacherous leak under pressure. ${ }^{25}$

She was recruited as a spy for a new mission in Antwerp, where she met again her friend and mate William Scot, she would later have described this experience as unusual with [her] sex and to [her] years. ${ }^{26}$

Another aspect of her life which remains obscure is her love stories. She was married to John Behn for a very short time. He, whose identity is doubtful, had probably been a slaver since at least $1655 .{ }^{27}$ Another interpretation of this liaison is that Aphra may be married to a man she had met on her way to Surinam or in Surinam itself. Mr. Behn probably was a seaman of German or Dutch origins. It is also likely that she invented his figure to create a more respectable status for a lady of her own position in society. ${ }^{28}$ According to Janet Todd's views,

Aphra probably married partly for money. Her irritation when she discovered there was not as much as she had hoped and that Mr Behn's property was shares in ships which it was impossible to realise may have fuelled her contemptuous descriptions of wedded sex. [...] she had made the wrong choice. ${ }^{29}$

After her husband's death, she found herself short of money. She realized that her options were limited. Three ways were offered to young women like herself in her society:

There was the possibility of a professional literary life, although there was no precedent for it, there was the chance of future espionage. One more commonly, there was marriage since she was now at the usual age for it, the mid-twenties. ${ }^{30}$

She tried and failed the last two contemplated chances: Her role as a spy was underestimated, notably, when she warned Home Office of an imminent Dutch attack of the fleet in the Thames ${ }^{31}$ and her husband died leaving her without money. ${ }^{32}$

When she went back in the spring of 1667, London was not a happy place. It was the year after The Great Fire, Behn found herself powerless to pay her debts. She expected the Crown would have paid her for her services as an agent. Conversely, she was left alone and was imprisoned for debts. ${ }^{33}$ It is not clear who had paid her debts off when she left the prison and started her theatrical career.

\footnotetext{
${ }^{24}$ Susan J. Owen. (2004). Behn's dramatic response to Restoration politics. In Derek Hughes and Janet Todd (Eds), The Cambridge companion to Aphra Behn. Cambridge, Cambridge University Press, p. 68.

25 J. Todd. The secret life of Aphra Behn, op. cit., p. 31.

${ }^{26}$ William J. Cameron. (1961). New light on Aphra Behn. Auckland, University of Auckland Press, p. 39.

27 A. Goreau. Reconstructing Aphra, op. cit., p. 85.

28 A. Behn. Oroonoko: The Rover and other works, op. cit., p. 5.

29 J. Todd. The secret life of Aphra Behn, op. cit., p. 71.

${ }^{30}$ Ibid., p. 67.

31 A. Goreau. Reconstructing Aphra, op. cit., p. 105.

32 J. Todd. The sign of Angellica, op. cit., p. 70.

33 Ibidem.
} 
Being a lady without money or protections, the only possible option for a poor woman like herself was to write in order to gain bread. The theatres had reopened and two were the most important theatrical companies. One of these, the King's company was Killigrew's, the other one, The Duke's Men was directed by Sir Danevant. ${ }^{34}$ It seems that she was introduced into court circles and the theatre through some family connection $^{35}$ and, maybe, through Sir Thomas Killigrew. She worked for him by readapting old plays. ${ }^{36}$

After having lived a terrible experience marked by financial straits, she promised herself she would not be without money anymore. Maybe, she became a kept woman, an actress, or a whore. ${ }^{37}$ If we agreed with some critics who tend to identify Aphra Behn with one of the characters of The Rover, Angellica Bianca, we would read in this latter's words Behn's credo:

The man is brave and generous, but of a humor so uneasy and inconstant that the victory over his heart is as soon as lost as won; a slave that can add little to triumph of the conqueror. But inconstancy's the sin of all mankind, therefore I'm resolved that nothing but gold shall charm my heart. ${ }^{38}$

Perhaps she acted. Probably she was writing part time before arriving fully fledged on the literary scenes in $1670 .{ }^{39}$

In 1670, she started her career as a writer and playwright. Her first work was The Forc'd Marriage, and it was followed by The Amorous Prince. ${ }^{40}$

The Forc'd Marriage or the Jealous Bridegroom is a tragicomedy, where Erminia, the heroine, is forced by her father and the king to marry Alcippus, a young warrior whom she does not love. Furthermore, the man she loves and who loves her is the prince Philander, the king's son. In the same way, Philander's sister and king's daughter, Galatea, is in love with Alcippus. The title already suggests one of Aphra's unflagging favourite themes in her works. ${ }^{41}$

The Amorous Prince was the first of her plays to be noted, the subplot was based on an episode called "the curious impertinent" from Cervantes' Don Quixote. ${ }^{42}$ Behn was fascinated by Spanish intrigue plots and rigid misogynist Spanish or Italian society, which she tended to see as essentially comic material. ${ }^{43}$

The great failure accomplished with her third work, The Dutch Lover disheartened Behn, who disappeared for a while. ${ }^{44}$

During this period, she had an affair with John Hoyle, son of a parliamentarian alderman from Yorkshire. ${ }^{45}$ This bisexual figure will appear several times in Behn's works, particularly in "Our Cabal", where the writer proclaims that sex and politics are not distinct, and as the "Fair Clarinda" in different poems. Hoyle appears in "Our Cabal" as a dark, arrogant, and silent man, with "fierce black eyes, who trifled with women". 46 He had a great influence on her, Todd writes on this point:

\footnotetext{
${ }^{34}$ Simon Trussler. (1986). An adaptation of The Rover (The banished cavaliers). Stratford-Upon-Avon, Methuen, p. 11.

35 A. Goreau. Reconstructing Aphra, op. cit., p. 12.

36 A. Behn. Oroonoko: The Rover and other works, op. cit., p. 5.

37 Ibid., p. 7.

38 A. Behn. Oroonoko: The Rover and other works, op. cit., Act II, Scene I, vv. 200-205.

39 Ibid., p. 7.

${ }^{40}$ M. A. O'Donnell. Aphra Behn: The Documentary record, op. cit., p. 5.

41 Ibid., p. 6.

42 Dolors Altaba-Artal. Aphra Behn's English feminism, op. cit., p. 54.

43 J. Todd. The secret life of Aphra Behn, op. cit., p. 149.

${ }^{44}$ M. A. O'Donnell. Aphra Behn: The documentary record, op. cit., p. 5.

45 J. Todd. The secret life of Aphra Behn, op. cit., p. 162.

${ }^{46}$ Ibid., p. 175.
} 
Hoyle dominated her thoughts but she did not dominate his. She responded more quickly than he and could not hold back. Here Behn was falling in love into conventional gender stereotypes and she knew it: the loving female and self-reliant male. ${ }^{47}$

After her absence from the scenes, she came back on the stage with her first tragedy, Abdelazer, "the embodiment of obsessive female love or lust in a work that circles round the themes of sexual submission and domination". ${ }^{48}$ In Behn's only tragedy the questions of usurpation, right to rule, political morality and law are underlined and investigated. ${ }^{49}$ Abdelazar was followed by The Town-Fopp , but she would win her best success with The Rover; or The Banish'd Cavaliers the following year. ${ }^{50}$

She probably attended the bohemian areas of the City where she met the Young Earl of Rochester, who became her friend, who probably inspired her The Debauchee. She liked young lawyers, witty not overly serious men. ${ }^{51}$ She preferred the court which stimulated her mind and wit than the bourgeoisie which was a closed world where free access was exclusively for men.

Under Charles II's reign, as I have argued in the previous chapters of this work, the king encouraged women to play female roles. The arrival of actresses greatly affected the presentation of female characters, since the body of the woman on the stage was heavily sexualized. ${ }^{52}$

As such actresses of her time as Nell Gwyn, Moll Davis, and Elizabeth Barry, Aphra was quite famous and, in the same way, considered as a new "fangled-whore". ${ }^{53}$ As Janet Todd has argued, her figure made a weird impact on men: "[Men were] perhaps a little worried about addressing an emancipated theatrical woman who seemed to want the freedoms of a man within the sexual game, while needing the homage due to feminine woman". 54

"She was a political animal". She showed her aggressive verve in Sir Patient's Fancy, the Roundheads and the City-Heiress, written in the years from 1678 to $1681{ }^{55}$ Her indignation in the regards of the Whigs was particularly due to events which led to the exclusion of James, Duke of York, from the succession to the throne. ${ }^{56}$ "She never ceased to denigrate the money-guibbing merchants of the City and in Sir Patient's Fancy, she ferociously depicted a merchant family as counting self-indulgence with censure. Always she scorned merchant virtues of thrift, sobriety, moderation and lifelines". ${ }^{57}$

In 1682, Behn attacked the Whigs and Monmouth in her epilogue to Romulus and Hersilia, her first known commission, an anonymous Roman tragedy, which cost her and the actress who claimed the epilogue, Lady Slingsby, alias Mary Lee, imprisonment. ${ }^{58}$

After Rochester's death, she wrote the prologue of his Valentinian; then, she wrote the epistolary novel Love-Letters between a Noble-Man and his Sister, set in the early years of Louis XIV's reign, where Philander falls in love with Sylvia, sister of his wife Mertilla. They start an exchange of letters which narrates their

${ }^{47}$ Ibid., pp. 175-176.

${ }^{48}$ Ibid., p. 186.

49 Ibid., pp. 187-188.

50 A. Behn. Oroonoko: The Rover and other works, op. cit., p. ix.

51 J. Todd. The secret life of Aphra Behn, op. cit., p. 123.

${ }_{53}$ A. Behn. Oroonoko: The Rover and other works, op. cit., p. 8.

53 J. Todd. The secret life of Aphra Behn, op. cit., p. 135.

${ }^{54}$ Ibid., p. 163.

${ }_{55}^{5}$ M. A. O'Donnell. Aphra Behn: The documentary record, op. cit., p. 6.

${ }^{56}$ Ibidem.

57 J. Todd. The secret life of Aphra Behn, op. cit., p. 70.

58 M. A. O'Donnell. Aphra Behn: The documentary record, op. cit., p. 6. 
deepest secrets and desires. Upon being discovered, Sylvia is warned about Philander's insincerity. Many complications would hinder the story that ends with a last letter, written by Philander who invites Sylvia to join him for their escape. ${ }^{59}$

As Ros Ballaster has written,

Behn's narrative takes a direction which may have been a surprise even to its author in that it moves beyond a representation of a determining power of language and outward for with which it opened, to imply the chaotic, haphazard, and contingent nature of desire, political, social and economic. Ultimately, life is a gamble and its winners and losers are the product of opportunity and circumstance rather than value. ${ }^{60}$

In the last years of her life, she collected her poems together with other authors', known as Poems upon Several Occasions. ${ }^{61}$

In 1688, she wrote two of her most significant works which contributed to the evolution of the novel, Oroonoko and The Fair Jilt. ${ }^{62}$

Oroonoko is the first novel which deals with Colonialism and Slavery, showing the cultural complexity and contradictions of Behn's times. "Combining Realism and Romance", ${ }^{63}$ it chronicles the story of Oroonoko, a young noble prince and his wife Imoinda. She is destined to be one of the king's wives, who gave her the sacred veil. The discovery of the marriage of the two lovers and the subsequent lost of her virginity led the king to sold her as a slave in a foreign land, Surinam. Oroonoko is soon betrayed and captured by an English captain who had planned to sell him and his men as slaves. Even though Oroonoko gains the confidence of his English captors, his desire for freedom will lead him to death.

As Janet Todd has underlined in her "Introduction to Oroonoko", "Aphra Behn did not have the modern concept of slavery", but "she did have the sense of improper commodification of human being for money". 64 By its representation of slavery, colonialism, race, class, and gender, Oroonoko deals with overwhelming preoccupations of Behn's society.

As many critics have observed, Oroonoko provides "a scathing critique of certain aspects of modernity with a full acceptance of others". ${ }^{65}$ This view shows us a contradictory Behn who is split between her loyalty to the king and the noble race and that idea of modernity which involves freedom from injustice and brutality.

The impressiveness of Aphra Behn was that none among her contemporaries wrote as much as she did. She was second only to Dryden. She fascinated and amused her public with tragedies, comedies, poems, comic plays, and French and Latin translations, as well.

She was the "abominable vile" accused by Burnet, ${ }^{66}$ because of her rashness, impudence, and resoluteness to assert herself as a writer. The accounts of her life are a succession of events characterised by words such as maybe, perhaps and probably, which underline the only certainty we are left with: she was a great writer.

\footnotetext{
${ }^{59}$ Ros Ballaster. (2004). "The story of the heart": Love-letters between a noble-man and his sister. In Derek Hughes and Janet Todd (Eds.), The Cambridge companion to Aphra Behn. Cambridge, Cambridge University Press, p. 141.

${ }^{60}$ Ibid., p. 149.

61 A. Behn. Oroonok: The Rover and other works, op. cit., p. 13.

${ }^{62}$ M. A. O'Donnell. Aphra Behn: The documentary record, op. cit., p. 7.

${ }^{63}$ Laura J. Rosenthal. (2004). Oroonoko: Reception, ideolgy, and narrative strategy. In Derek Hughes and Janet Todd (Eds.), The Cambridge companion to Aphra Behn. Cambridge, Cambridge University Press, p. 161.

${ }_{64}$ Aphra Behn. (2003). Oroonoko. Janet Todd (Ed.). London, Penguin Classics, p. XXIII.

65 Ibidem

66 A. Behn. Oroonoko, The Rover and other works, op. cit., p. 21.
} 


\section{Conclusion}

Throughout her works and her life, Behn tried to change woman's condition. We cannot label her a "Feminist", but her "central feminist issue was woman's rights to sexual freedom equal to that of man, and she insisted by her writings and her example that woman had sexual desires that deserved as much respect as those of men". She contributed to modify woman's self-perception, even if the results were not immediately evident. She claimed 'the same right as their male counterparts to 'Rove' and if necessary to play 'trick for track'. Here as elsewhere in works in this tradition, the impulse toward domination and the desire for freedom are closely intertwined".

Aphra Behn "embraced the title of whore, by writing bawdy comedies". Absolutely in line with her contemporaries' sexual allusions, Aphra Behn wrote in The Rover:

WILLMORE: a pox of fear: I'll be baked with thee between a pair of sheets, and that's thy proper still; so I might but strew such roses over me and under me. Fair one, would you give me leave to gather at your bush this idle month; I would go near to make somebody smell of it all the year after.

Using an allusive language as only a man could do, she "capitalised her supposed handicap".

As Catherine Gallagher has argued, Behn contrasted "the ways in which men exercise economic control over women, whether wives, daughters, servants or prostitutes". Behn took conventional dramatic forms but, by emphasizing these themes, she imbues them with a unique, even a feminist vision.

\section{References}

Ballaster, R. (1998). Seductive forms: Women's amatory fiction from 1684-1740. Oxford: Clarendon Press.

Cameron, W. J. (1961). New light on Aphra Behn. Auckland: University of Auckland Press.

Finke, L. (1993). Aphra Behn and the ideological construction of Restoration literary theory. In H. Hutner (Ed.), Rereading Aphra Behn: History, theory, and criticism (pp. 17-43). Charlottesville and London: University Press of Virginia.

Gallagher, C. (1999). Who was that masked woman? The prostitute and the playwright in the comedies of Aphra Behn. In J. Todd (Ed.), Aphra Behn (New casebooks) (pp. 12-31). New York: St. Martin's Press.

Goreau, A. (1980). Reconstructing Aphra: A social biography of Aphra Behn. New York: Dial.

Hughes, D., \& Todd, J. (Eds.). (2004). The Cambridge companion to Aphra Behn. Cambridge: CUP.

Markley, R. (1995). "Be impudent, be saucy, forward, bold, touzing and leud": The politics of masculine sexuality and feminine desire in Behn's Tory comedies. In D. J. Canfield and D. C. Payne (Eds.), Cultural readings of Restoration and eighteenth-century English theatre (pp. 114-140). Athens and London: The University of Georgia Press.

Owen, S. J. (1996). Sexual politics and party politics in Behn's drama (pp. 1678-1683). In J. Todd (Ed.), Aphra Behn studies (pp. 15-29). Cambridge: CUP.

Pearson, J. (1988). The prostituted muse: Images of women \& women dramatists (pp. 1642-1737). New York and London: Harvester-Wheatsheaf.

Spencer, J. (1986). The rise of the woman novelist, from Aphra Behn to Jane Austen. Oxford: Basil Blackwell.

Spencer, J. (1993). "Deceit, dissembling, all that's woman": Comic plot and female action in the feigned courtesans. In H. Hutner (Ed.), Rereading Aphra Behn: History, theory, and criticism (pp. 86-101). Charlottesville and London: University Press of Virginia.

Spencer, J. (2000). Aphra Behn's After Life. Oxford: Oxford University Press.

Todd, J. (1989). The sign of Angellica: Women, writing, and fiction, 1660-1800. London: Virago.

Todd, J. (2000). The secret life of Aphra Behn. London, New York, Sidney: Pandora.

Trussler, S. (1986). An adaptation of The Rover (The banished cavaliers). Stratford-Upon-Avon: Methuen.

Wilmot, J. (2002). Love a woman. In P. Hammond (Ed.), Restoration literature, an anthology. Oxford: Oxford University Press. 